\title{
Deconstructing Self-Similarity and the Four Dis-similitudes of Biodiversity
}

\section{Allaerts W* \\ Biological Publishing A\&O, The Netherlands}

\section{Review Article}

Volume 4 Issue 2

Received Date: May 04, 2021

Published Date: June 02, 2021

DOI: $10.23880 /$ phij-16000180

Dol: $10.23880 / \mathrm{phij}-16000180$ Netherlands

\section{Abstract}

Faced with the problem of defining a global biodiversity estimate in terms of a fractal Global Ecosystem Approach and tackling the problem of interactions between trophic levels, in this paper the notion of biodiversity is analyzed from a different angle. The classical viewpoint of biodiversity is to count the numbers of species within a given framework, mostly a selected part of an ecosystem. The counting is based on the self-similarity of the elements in the chosen domain, basically the species within a community or specific trophic layer of the ecosystem. An opposing viewpoint is to regard the levels that generate biodiversity in all of its aspects, for instance the natural processes that alter uniform anthropogenic plants. We here elaborate on an hermeneutic scaffold of the four similitudes and their signature in sixteenth century epistemology, as documented and discussed in Michel Foucault's The Order of Things $(1966,1970)$. In the transition from late medieval epistemology to modern natural sciences, they appear to contribute to the definition of the four dis-similitudes of biodiversity presented in this paper: chemodiversity, genodiversity, phenodiversity and ecodiversity. The idea of Nature as an infinite source of divisions and distributions, not only was expressed in Foucault's work, it also was detected in one of Charles Darwin's letters to J.D. Hooker. These letters were written before Darwin published his most famous work The Origin of Species (1859). Not only the present contrast in viewpoint of dissimilitude rather than of similitude, offers the possibility of an escape from the anthropocentric view on species-related biodiversity. For, this current, dominant view on biodiversity is well defined in higher vertebrate and some specialized invertebrate taxa, but is less sufficient to describe biodiversity in bacteria, fungi and socalled lower biological taxa. Also the Ecological Counterpoint as may be observed in these modest forms of nature, may help us to re-consider several continuing challenges of our post-modern way of life. Moreover, the case study of Saproxylic beetles and forest ecodiversity illustrates how neoliberal and political sustainability discourses may benefit from a deepening of the ecological debate and from a philosophical analysis of its foundations.

Keywords: Self-Similarity; Similitude and Dis-similitude; Biodiversity; Ecological Counterpoint; Saproxylic Beetles and Forest Ecodiversity

\section{Introduction}

One of the most frequent used notions in political sustainability discourse is the notion of biodiversity. However, exact and unbiased estimates of biodiversity that account for interactions between multiple trophic levels are very hard to establish at a global scale. ${ }^{1}$ On the other hand, the Unified Neutral Theory of Biodiversity and Biogeography (UNTB) as presented by S.P. Hubbell, ${ }^{2}$ not only discards

1 Allaerts W (2020).

2 Hubbell SP (2001). 
the interactions between trophic levels, it also introduces a disturbing gate-keeping mechanism and predicts distributions which may contrast with experimental data of several meta-communities in a wide variety of ecosystems. Moreover, the critical percolation probability of a hierarchical cluster, which relates to the stability of an ecosystem with multiple trophic levels, has been established following the comparison of inter-trophic interactions. ${ }^{3}$ Finally, the unbalanced preferential treatment of large species of game or spectacular big carnivores and favorites of safari parks, may not be helpful for monitoring biodiversity impairment in the unseen territories of the organisms inhabiting soil, the uncharted oceanic depths and other terrae incognita.

However, it wasn't our aim to criticize Hubbell's UNTB, or to eliminate all forms of gating principles. Gating principles refer to the hermeneutic toolkit of defining what is comparable and what extends beyond comparison, and therefore, to the very distinction between what is similar and what is different. In this way, gating principles are inherent to modern natural sciences. Moreover, they may have generated the basis of the contemporary conundrum of tackling biodiversity at a global, multiple levelled trophic ecosystem including bacteria, fungi and other taxa where a majority of the species is either undefined or undiscovered. In order to circumvent the obvious swamps of misjudgment and misinterpretation, to our opinion, a philosophical query into the essential notions of (Self-) similarity (see $\mathbb{P} 2-3$ ) and (bio-) diversity (see $\mathbb{P} 4-5$ ) may form a necessary basis for further analysis.

In the present review, results of both recent theories on the notion of Self-similarity (similitude) and historical studies on the origin of the notion of dis-similitude or diversity are combined in a new synthesis. The analogy with the notion of counterpoint in music (a musical composition consisting of themes and anti-themes) is borrowed from authors like Douglas R. Hofstadter and Guerino Mazzola (see $\mathbb{P}$ ). In the present paper the focus is on its ecological applicability, therefore named 'Ecological Contrapunctus' (of themes and anti-themes). The results of this philosophical and ecological investigation are compared with the present status of international programs for ecological sustainability and biodiversity conservation, applied to the case study of the protection of Saproxylic beetles (see $\mathbb{P} 6$ ).

\section{De-constructing Self-Similarity and Association}

According to the famous French music composer Pierre Boulez (1925-2016), the driving forces of nature are 'repetition and association.' ${ }^{4}$ It has been noted that repetition not only results in the replication of cells and generation of offspring, but also generates all kinds of self-similarity and thus may form a basis for the fractal appearance of nature and natural forms. But how do these mechanisms of selfsimilarity and association actually work? The following thought experiment on the construction of a roof with equal tiles may shed some light.

Consider the following elements $\cap,-$ and $\backslash$, respectively (Word ${ }^{\mathrm{TM}}$ ) symbol signs 199, 190 and a double backslash. We may combine them under an angle of some 100 degrees, generating a morphology as shown in the following drawing in Figure 1. In this example, self-similarity is accomplished by the combination of repetition (a regular subdivision of a given area of the plane) and the fixed association between the 3 elements. What results is the image of a roof of tiles; we may add some additional color in some of the tiles, and additional rules, like that no two blue tiles may become juxtaposed to one another. However, to really make it look like a roof surrendered to the forces of nature, we may draw the overgrowth of some green algae or lichens. These cellular organisms do not follow the similarity imposed by the tilers construction, but follow different directions or associations with 3D-elevation, preferred wind direction et cetera.

Self-similarity is also achieved by a regular partitioning or subdivision of the plane, e.g. following the application of (so-called golden) ratios of subsequent numbers of the Fibonacci series (see Figure 2).

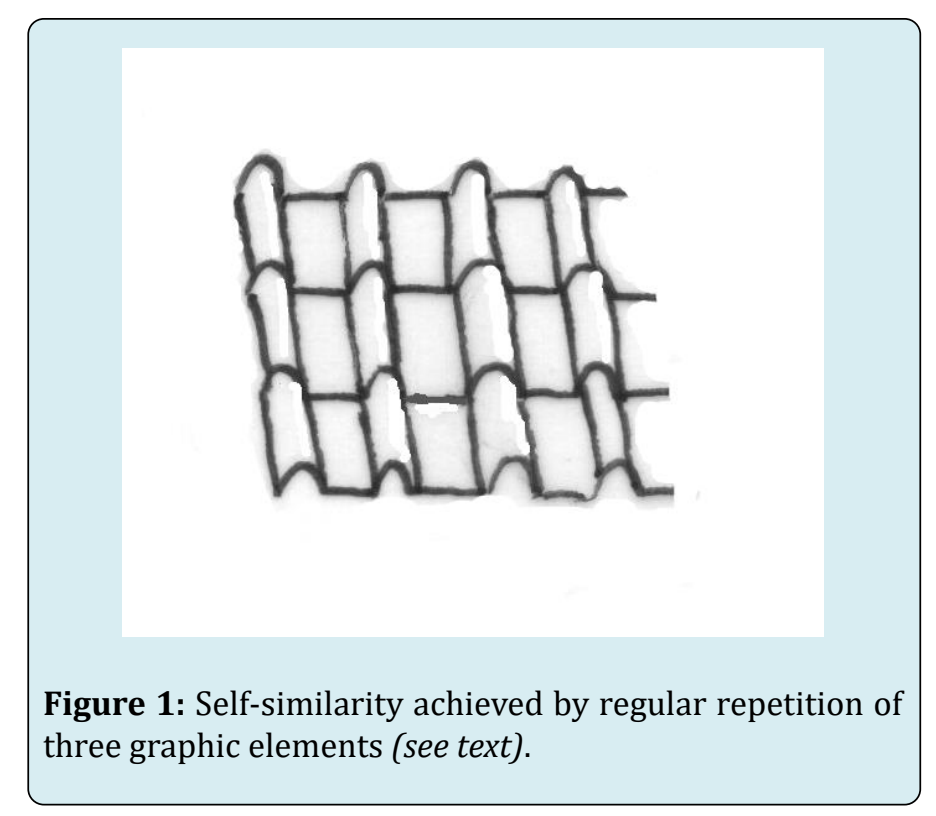

Figure 1: Self-similarity achieved by regular repetition of three graphic elements (see text).

4 Nederlandse Publieke Omroep (NPO)(2020). 


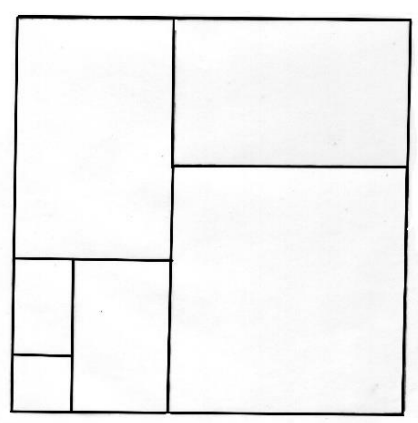

Figure 2: Self-similarity achieved by a series of subdivisions of a square, according to the ratios of the numbers of a Fibonacci series $1 ; 1 ; 2 ; 3 ; 5 ; 8 ; 13 ; 21 ; 34 ; 55$; $89 ; \ldots$ (see also [1]). The ratio's $1 / 2,2 / 5,3 / 8,5 / 13,8 / 21$, $13 / 34,21 / 55,34 / 89, \ldots$ equal the following, fluctuating but convergent sequence: $0.500 ; 0.400 ; 0.375 ; 0.385 ; 0.3809$; $0.3824 ; 0.3818 ; 0.3820 ; 0.3819 \ldots$ which is related to the so-called (inverted) 'golden ratio' (see also legend to Figure 4).

When we add new associations, the resulting morphologies at some point will resemble the conditions met in actual living organizations. Conditions such as avoidance, competition, reciprocity may come into picture, some of them may remind us of a warm summer evening when large colonies of Starlings (Sturnus vulgaris) yield peculiar dark clouds in the sky. The conditions regulating the distance between the individuals indeed appear to be the same conditions, resulting in the formation of schools of fish, herds of reindeer, flocks of birds, et cetera. ${ }^{5}$ Although the groups consist of thousands of individuals, as a whole these groups may rapidly change their morphology, for instance in order to escape the attacks from predators.

As demonstrated by Benoit Mandelbrot (1924-2010) (see Figure 3), a self-repeating, regular partitioning of the plane may generate pictures resembling umbel forming flowers, reminiscent of the inflorescences of the Umbelliferae. According to Mandelbrot, ${ }^{6}$ the fractal approach may be regarded as an alternative to the continuous and smooth transformations of one species into another: this technique "in the spirit of Euclid", according to Mandelbrot, was made famous by D'Arcy W. Thompson (1860-1948) in his pioneering work On Growth and Form (1917), a book about "the way things grow, and the shapes they take" (fide

\footnotetext{
5 Reynolds CW (1987).

6 Mandelbrot BB (1983), pp. 155
}

J.T. Bonner). ${ }^{7}$

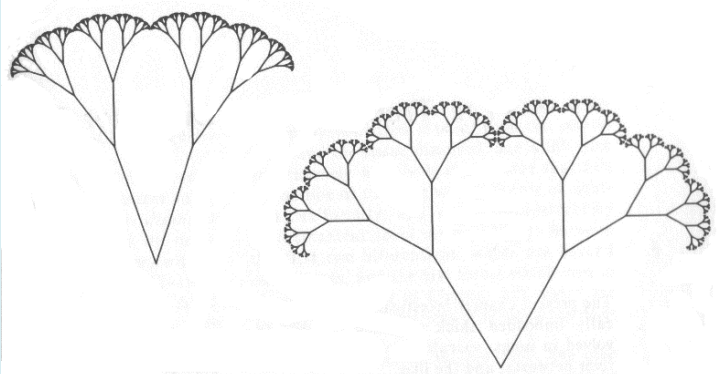

Figure 3: Self-similarity in the form of bifurcation patterns, resembling inflorescences of Umbelliferae, adapted from Mandelbrot's Fractal Geometry of Nature [6].

But when we move from representations on a 2D-screen to the real world, some obvious gating principles necessarily cross our path: the question of the size of the organism (at which magnification, under a microscope? Or, from which distance can they be automatically detected by remote sensing?), the question to which trophic level the organisms belong and, last but not least, the question of intra-species variation or the notion of speciation in itself. How do we have to understand self-similarity in nature?

In the illustrious work of Douglas R. Hofstadter $\left({ }^{\circ} 1945\right.$, New YorkCity, NY) Gödel, Escher, Bach (1979) ${ }^{8}$ a lot of emphasis is put on the notion of self-reference (idioms) and recursive processes as a basis for complex organization. Similarly, in the work of Diego L. Rapoport, ${ }^{9}$ a topological approach for self-referential biological systems using the Klein Bottle topology is followed, designated as Klein Bottle logophysics (after Felix Klein [1849-1925], the inventor of the Klein bottle, an object that combines the topological features of the torus and the Möbius-strip). In continuation of our earlier discussion of implementing topological theory in biological morphogenesis, ${ }^{10}$ we prefer to adhere to the Thomistic adage (referring to the work of René F. Thom, 1923-2002), stating that although a topological characterization of biological objects is possible, the thermodynamic equivalent of these topologies cannot be defined. ${ }^{11}$ Moreover, in the present analysis, we are more interested in the diversity of nature than in the self-similarity of objects as they are found in the biological world. However, before to proceed with the notion of diversity or dis-similitude, in the following paragraph,

\footnotetext{
7 Thompson DW (1917, 1961 Ed.)

8 Hofstadter DR $(1979,1985)$.

9 Rapoport DL (2011).

10 Allaerts W (1999).

11 Thom R (1974).
} 


\section{Philosophy International Journal}

we will first have to dive into a further de-composition of the notion of similarity. Haphazardly, we ran into the four similitudes, as revealed from sixteenth century literature by Foucault (1966). ${ }^{12}$ From a peculiar, so-called 'dark space', a remnant of residual ignorance (see $\mathbb{P} 3$. The Four Similitudes of Sixteenth Century Epistemology), we may proceed to the different realms of biodiversity as encountered in modern scientific literature (see $\mathbb{P}$. The Four Dis-similitudes of Biodiversity).

\section{The Four Similitudes of Sixteenth Century Epistemology}

In Michel Foucault's (1926-1984) philosophical treatise Les Mots et les Choses (1966), translated in English as The Order of Things (1970) ${ }^{12}$, a genealogy - or 'archaeology' in Foucault's own words - is provided of the (post) modern human sciences. In the first part (Chapter 2: The Prose of the World), Foucault starts with a description of the four similitudes in epistemological literature in the second half of the sixteenth century. In order to describe 'resemblance' in the late age of scholastic tradition, the four similitudes are:

1) Convenientia, explained as close adjacency (juxtaposition) of things, a resemblance which is "connected with space in the form of a graduated scale of proximity". ${ }^{13}$

2) Aemulatio, a "sort of convenience that has been freed from the law of place and is able to function, without motion, from a distance",14 something like the reflection of an image in the mirror or light images "scattered through the universe".

3 ) The concept of analogy, a notion already "familiar to Greek science and medieval thought", but which in late sixteenth century literature was rather a combination of "convenientia and aemulatio superimposed". 15 And finally, the notion of sympathies, which "plays through the depths of the universe in a free state". 16

It is very remarkable that the first example of convenientia, listed by Foucault, is the 'convenience' of body and soul, "because the soul had to be made dense, heavy, and terrestrial for God to place it in the very heart of matter (...)", although "the body is altered and corrupted by the passions of the soul". And for the emulation of the human face in the sky, "just as man's intellect is an imperfect reflection of God's wisdom (...)", as well as examples of the emulation of Venus in the kissing mouth, the image of Jove's scepter and Mercury's staff, all corroborate the pre-modern, late medieval state of the sciences in the sixteenth century. Also, the free-moving

\footnotetext{
12 Foucault M (1966; Engl transl 1970)

13 Foucault M (1970), p. 18.

14 Foucault M (ibidem), p. 19.

15 Foucault M (ibidem), p. 21.

16 Foucault M (ibidem), p. 23.
}

sympathy results in all kinds of assimilations between animals and plants but also in its compensating twin, the antipathy or hatred, like in the mythical Indian story of the rat, being "pernicious to the crocodile (...), sleeping with its jaws agape, it makes its way through them and slips down the wide throat into the crocodile's belly $(. .). "{ }^{17}$ Although this story rather refers to mythical beliefs or pernicious fantasies, it clearly illustrates the interconnectedness of pre-modern natural descriptions and scholastic philosophy, as Foucault explains: "And yet the system (of four similitudes) is not closed (...). There are no resemblances without signatures (...). It is sympathies and emulations that indicate analogies (...) ${ }^{\prime 18}$. It is thanks to the 'revolution' of modern science, often associated with the philosophies of Descartes, Spinoza, Leibniz and the pioneering oeuvres of Galilei, Copernicus, Newton, among others, that "the circle of resemblance was broken". ${ }^{18}$ This means that the sixteenth century discourse, which was a discourse (hermeneutics and semiology) of 'similitude', was progressively replaced by a discourse of 'difference' (dis-similitude), assisted by the developments in mathematics. This development according to Foucault resulted in the notion of mathesis, the fundamental thesis of the world as a place of measurable differences (although differential calculus wasn't yet available at the hands of the early pioneers).

However, before the modern natural sciences deployed their grid over the modern world, there was "a slight degree of non-coincidence between the resemblances", resulting in domains where "the grid is less easy to see through; its transparency is clouded over from the very first". ${ }^{19}$ This is wat Foucault denotes as the realm of nature: "A dark space appears which must be made progressively clearer. That space is where 'nature' resides, and it is what one must attempt to know".

It is the remnant of this 'dark' space that in our postmodern world still marks the grid of our ignorance and the contours of the remaining areas to become uncovered. But the compound notion of 'biodiversity', by the nature of progress of the natural sciences themselves, is marked by a fourfold re-allocation. We call them the four dissimilitudes of biodiversity: the realms of Chemodiversity, Genodiversity, Phenodiversity, also known as Phylodiversity, and Ecodiversity (see section below).

\section{The Four Dis-similitudes of Biodiversity}

1) Chemodiversity: The Periodic Table of elements (after

\footnotetext{
17 Foucault M (ibidem), p. 24.

18 Foucault M (ibidem), p. 17-30.

19 Foucault M (ibidem), p. 30.
} 


\section{Philosophy International Journal}

Dmitri I. Mendeleev, 1834-1907) not only represents the known chemical constituents (so far there are 118 known elements $)^{20}$ of our planet Earth, they are also the elements found in other planets, stars and (inter)galactic clouds (with hydrogen and helium being by far the most common elements). ${ }^{21}$ The chemical substances in the universe thus generate a realm of chemical principles and building blocks, e.g. the ions, complexes and (macro)molecules that give rise to the immeasurable richness of possible known and still unknown substances.

This is especially true for the chemical substances found in living beings on our planet Earth, but obviously not all chemical elements are compatible with (all) forms of living organization. For instance, apart from the micro-organisms in some sulfur-rich hot water springs, few micro-organisms will survive the presence of arsenic and derived compounds (like thio-arsenates). It is thought that these hot water spring conditions are very similar to the conditions that probably existed in the early geothermal phases of our planet. ${ }^{22}$ In order to detoxify arsenic, micro-organisms like those of the genus Sulfurihydrogenibium (bacteria belonging to the phylum Aquificae, order of Aquificales), express enzymes called reductases that for instance are capable of converting arsenate into arsenite, ${ }^{23}$ and so on. In order to identify the micro-organism expressing a particular enzyme that is capable of a specific chemical reaction, a metagenomics analysis of the complete (16S ribosomal) RNA gene 'pool' of all microorganisms at the combined sample sites of the hot water pools (i.e. the Champagne Pool in New Zealand) has been conducted. Correlation of gene diversity at the different sample sites then resulted in relating the enzymes to the microbial organisms at the genus level (only). It is wellknown that exchange of hereditary material between strains of micro-organisms is a widespread mechanism that largely hampers the identification of micro-organisms at the species level (see below).

For the majority of organisms on Earth, however, a limited number of elements are far more important than the former ones, found in these rare micro-organisms. Moreover, phosphor, an element of the same group as arsene, is in fact a rate-limiting element for the growth of most organisms, due to its role in constituting the (sugar-) phosphate backbone of DNA and RNA macromolecules (see also Figure 4). Referring to the important role of nitrogen in the present discussion of agriculture-induced biodiversity loss (see below), it is tempting to look at the proportion of nitrogen mass to total

20 IUPAC (2004).

21 Trimble V (1996).

22 Hug K, Maher WA, Stott MB, Krikowa F, Foster S and Moreau JW (2014).

23 Gladysheva TB, Oden KL and Rosen BP (1994). molar mass in these moieties that are important for passing the genetic material and from one generation to another, and from cell to cell within the organism (Figure 4).

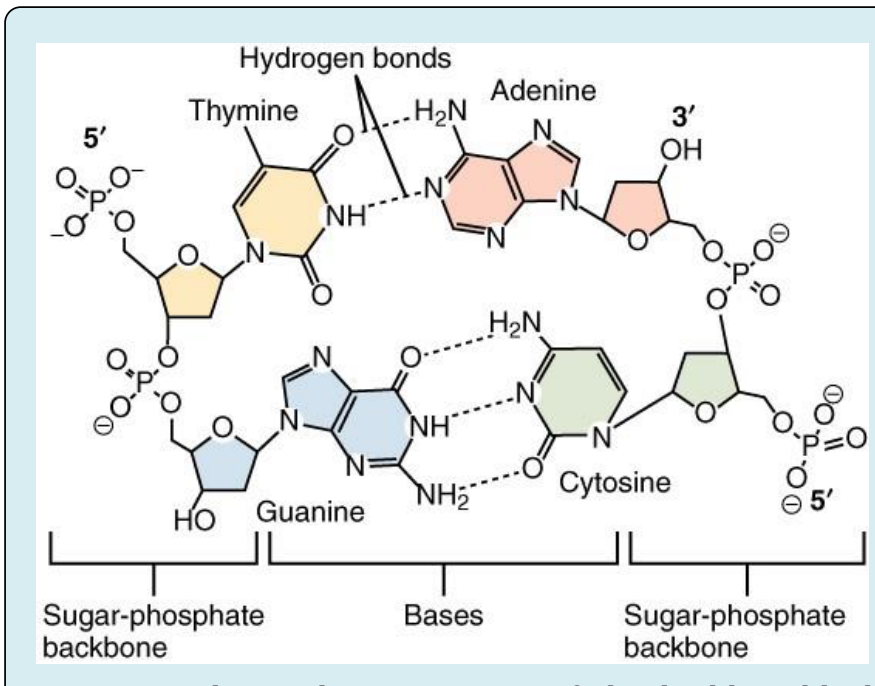

Figure 4: Chemical composition of the building block and constituting elements of the DNA double helix. The bases are nitrogen-rich moieties with bear an unequalled role in preserving the organisms inheritance as well as a remarkable feature: namely, the ratio of nitrogen mass to molar masses of the adenine + thymine pair equals $98.07 / 256.92=0.3817$ and for the guanine + cytosine pair it equals $112,08 / 250,24=0.4479$, which numbers fit well within the range of the (inverted) Fibonacci sequence of Figure 2. (Chemical structures from Wikipedia, Chemistry).

2) Genodiversity: Micro- and macro-organisms are well known to exhibit a variety of mechanisms in order to transmit genetic information mostly from one generation to another. This mechanism forms the basis of Ernst W. Mayr's (1904-2005) (see below) reproductive concept of species. In addition to sexual reproduction, in bacteria and presumably also in certain fungi, transfer of genetic material also occurs within one generation, i.e. before sexual reproduction takes place. In fact, these hereditary mechanisms endow species with the capacity to maintain a more or less stable pool of chemical characteristics in an environment with changing characteristics or to adapt towards a physicochemical modification of the environment. In chemical terms, the genetic material in the realm of viruses may consist of single or double-stranded RNA or DNA molecules, and their taxonomy is based on the distinctive pathways for mRNA synthesis.

Due to the huge exchangeability of genetic material, the International Committee on Taxonomy of Viruses (ICTV) in 1982 has defined a virus 'species' as "a cluster of strains" with unique identifying qualities. Between 1982 and 2013 


\section{Philosophy International Journal}

several new definitions of the virus species concept, ranging from a poly-thetic class of viruses (constituting a replicating lineage and occupying a particular ecological niche) towards a mono-phyletic group of viruses (whose properties can be distinguished from others by "multiple criteria"). ${ }^{24}$

3) Pheno/Phylodiversity: The phenotypic basis of speciation has for a long time been the only known basis to define a taxonomy of species, since genetics and genome analysis are relatively new branches on the tree of biology. From the formulation of the dual Latin name nomenclature of the Swedish botanist Carolus Linnaeus (1707-1778), to the catastrophe theory of Georges Cuvier (1769-1832), the successive evolution theories of Jean-Baptiste de Lamarck (1744-1829), Étienne Geoffroy Saint-Hilaire (1772-1844) and finally Charles Darwin (1809-1882) till the speciation theory of the German biologist Ernst Mayr, all have contributed to the development of the modern biological species concept. This however doesn't mean that the generation of the biological species concept was without controversy, for instance regarding the taxonomic principles chosen to establish some order in the vast reigns of plant and animal kingdoms (see Comte de Buffon's [1707-1788] criticism of Linné's nomenclature). ${ }^{25}$ Even Darwin, three years before the publication of The Origin of Species (1859), writes his friend Joseph Dalton Hooker (1817-1911) about the 'strange and laughable' habits of naturalists (biologists) to follow divergent paths to define what is called a biological 'species'. And he adds: "It all comes, I believe, from trying to define the undefinable". ${ }^{26}$ Between Darwin's oblique reference to the undefinable and Foucault's denotation of the realm of nature, which is the reign of "non-coincidence of resemblances" (see $\mathbb{P} 3$ ), a century of biological, tribal wars and tedious drudgery in the academic monasteries has filled the archival and even modern book shelves of taxonomy.

4) Ecodiversity: Whereas the divergent notions of speciation irrigated the controversies about taxonomy, which superfluously influenced the field of phenotypical biodiversity, the notion of ecodiversity still dwells on its infancy. Modern ecosystem ecology focuses more on the interactions of organisms within communities, or to their

24 Adams MJ, Lefkowitz EJ, King AM, Carstens EB (2013).

25 Duris P (2006).

26 "(...) It is really laughable to see what different ideas are prominent in various naturalists minds, when they speak of 'species' in some resemblance is everything \& descent of little weight - in some resemblance seems to go for nothing \& Creation the reigning idea - in some descent the key - in some sterility an unfailing test, with others not worth a farthing $\left({ }^{*}\right)$. It all comes, I believe, from trying to define the undefinable (...)“. Charles Darwin letter to J.D. Hooker, 24 December 1856, University of Cambridge Archives, Darwin Correspondence Project. (See: http://darwinproject.ac.uk) (*: A 'farthing' represents an ancient British monetary unit equal to $1 / 4$ of a penny, so here it is not a vulgar utterance). contribution to the cycling of nutrients and the flow of energy. However, older botanical studies are reminiscent of the (often German) studies on plant communities and their community-specific hallmarks. ${ }^{27}$

In 1985, the scientific field of 'Pflanzensoziologie' was officially installed in Germany, but no corresponding field of 'zoological sociology' (not to be confounded with Edward 0. Wilson's theory of Sociobiology) ${ }^{28}$ would match the efforts of the botanists to exceed the species level of organization. On the contrary, influential authors like Stephen Hubbell in $A$ Unified Neutral Theory of Biodiversity and Biogeography (2) discarded the inter-trophic and species-niche interactions in order to define a so-called 'neutral' theory of biodiversity (3).

Whether or not a diminished interest of the AngloSaxon literature in social cohesion (of natural organization) is tributary to this forgotten level of zoological interactivity, this hasn't been the case for the international and European legislator: at least the plant communities (or habitats as a specific domain for protection) have found their way to the Bern Convention. ${ }^{29}$ This may have resulted in the somewhat anomalous effects resulting from the Natura 2000 program. This program is intended to protect certain nature reserves, where specific plant communities are endemic and also wild animal species are supposed to occur, but the latter often fail to do so. Protection measures to maintain for instance a healthy population of Black-tailed Godwits (Limosa limosa) may not prevent a large scale influx of (hibernating or trespassing) geese flocks, which fact may even further reduce the chances for restoring a stable population of the desired Limosa species. A similar, recent example is found in the controversy between national goals for renewable energy management and nature conservation, referring to the protection of the European Honey-buzzard (Pernis apivorus) in the Netherlands: Pernis apivorus is a top species in the IUCN (International Union for Conservation of Nature) Red list of threatened bird species ${ }^{30}$ and an important key species according to the Natura 2000 program, ${ }^{31}$ among others based on the EU Habitats and Birds Directives. ${ }^{32}$ Plans to build large wind mills in the Hoge Veluwe National Park are considered a threat to the local population of the Pernis apivorus. But, amidst the jungle of official documents, the ecological relationship between the occurrence and partly insectivorous diet of the Honey-buzzard, specialized in

\footnotetext{
27 See e.g. Oberdorfer E (1957), and Runge F (1966).

28 Wilson EO (1975).

29 European Environment Agency (EEA) (1979).

30 Birdlife International (2015).

31 European Commission (2014a).

32 European Commission (2014b).
} 


\section{Philosophy International Journal}

larvae of wasps and hornets, ${ }^{33}$ is hard to find.

In the next paragraph, some mechanisms influencing specific interspecies interactions are discussed from another, rather unconventional viewpoint. Apparently, finding a comprehensive theory build on niche-species and speciesspecies interactions is still a challenging work-in-progress.

\section{Ecological Contrapunctus: themes and anti- themes}

In nature, it is notall about harmony and convenience (see P3. The Four Similitudes of Sixteenth Century Epistemology), but, as we may have learned from Darwinism, it is mostly about struggle and survival of the fittest. What can we say of the 'drama' of nature when compared to that other form of representation of the world we live in, namely: music? From a somehow synesthetic viewpoint we may compare the balance and struggle of nature with the battlefields and romantic sceneries evocated in music, such as in the works of great composers of the Baroque era.

In Western music history, the origin of the theory of contrapunctus (counterpoint) lays somewhere in the transition from the Renaissance era of Polyphony towards the Baroque era, with the Kunst der Fuge of J.S. Bach (1685-1750) considered as one of the earliest highlights. In the preceding, polyphonic tradition, counterpoint is achieved by the combination of two or more individual, independent melodies into a single harmonic texture. In the baroque tradition of Bach and contemporaries, the vertical interdependence of the different melody lines comes to the forefront, to increase the combined musical and textual expression of the individual lines. Recently, there has been an attempt to give counterpoint theory a mathematical foundation, ${ }^{34}$ including a logical synthesis for the practice of forbidden parallels of fifths and dissonant fourths. ${ }^{35}$ It is interesting to see how Guerino Mazzola (34) builds upon topology and certain ideas of Douglas R. Hofstadter, but these lines of inquiry would definitely reach beyond the scope of the present paper (for the importance of topology and self-reference idioms, see also Par. 2. Deconstructing Self-Similarity and Association).

From the ecological perspective, we should rather ask ourselves: what are the different lines or ecological chains that are interacting at the species level to constitute the 'drama' of nature, or that constitute something reminiscent of counterpoint in ecological diversity?

Macià FX, Menchetti M, Corbella C, Grajera J, Vila R (2019).

Mazzola G (2002).

Mazzola G (2017).
Referring to the classical body of ecological literature, it is well known that animals, plants, can be organized in food chains, from top predators towards the primary producers in the kingdoms of Bacteria, Algae, Fungi, et cetera. Otherwise, in plant communities a continuous struggle for the available source(s) of light results in the stratification of (rain) forests, the canopy constituting tree tops, the epiphytes (and, in particular, saprophytic plants), the Lichens, Musci and/or Bryophyta and Algae that cover the trunks and branches, and the plethora of organisms that cover the forest soil (where, on certain spots only limited sunlight comes through). In each chain, different trophic levels may be discerned. Another approach, that moreover incorporates the chemodiversity is the distinction between producers and reducers, the organisms involved in synthesis and decay, considered as the biochemical basis of ecology. In the ecological counterpoint depicted above, they constitute the themes and anti-themes of a local ecosystem.

What are the biochemical mechanisms that are underlying these processes? In the 'synthesis' department we find the photosynthesis of carbohydrates, and derived amino acids, polypeptides, DNA and RNA macromolecules. To the 'decay' department belong all types of lysis, e.g. in the digestive tract of all animals, but also in intracellular lysis in the lysosomes and peroxisomes - i.e. oxidative organelles within the cells - of most eukaryotic cells. It is obvious that the synthesis and decay 'departments' are interdependent and relying on the exchange of the same biochemical compounds for their respective chemical processes. Moreover, it is well documented that soil inhabiting fungi depend on photosynthesizing plants for their carbohydrate supply, and, in turn, mycorrhizal fungi provide nitrogen to the plants. ${ }^{36}$ Many plant species prefer nitrogen-poor soils, but the presence of certain dominant species will alter the chemical composition of the soil and induce the accumulation of soil organic matter, ${ }^{37}$ altering the chemical composition of the soil itself. This may for instance result in a tenfold increase in nitrogen mineralization. Finally, this accumulation drives the succession of plant communities, like for instance observed in heathlands. It is quite disturbing though, to decipher the trend in political discourses to blame nitrogen accumulation (especially following nitrogen emission from modern agricultural practice) as the principal or only reason for biodiversity loss, apart from the direct effect of climate change. This could result in the disregard of the ecological importance of nutrient-rich ecosystems like those found in reed marshes, in rural wooded banks piled up with thorn-bushes, etc. Despite the paucity of higher plant species in these micro-ecosystems, they may form very

36 Hestrin R, Hammer EC, Mueller CW, Lehmann J (2019).

37 Berendse F (1998). 
desirable habitats for coverage or nesting of Passerines or songbirds and other animals. Obviously, biodiversity is also about balance and proportionality.

Beside synergy, also competition and mutual intolerance occurs between the soil-inhabiting and other (micro-) organisms, like the well-documented anti-bacterial chemical compounds synthesized by fungi (e.g. of the genus Penicillium), or the anti-fungal chemicals that are correlated with mechanisms of bacterial resistance. ${ }^{38}$ Therefore, the ecological biodiversity not only relies on a well-balanced chemical and nutrient composition of the soil, but also on the growth and decay of individual trees (as special niches for other species). Even the succession of one plant community by another is an important mechanism in order to sustain the livelihood of an ecosystem. It is well known that the bark (and wood) of dead poplar trees (Populus sp.) forms a desirable habitat for hundreds of invertebrate species, such as bark beetles (see below), wood-lice, centipedes and millipedes. Otherwise, biodiversity estimates show that massive, oldage oaks (Quercus sp.) may constitute a local biodiversity 'hot spot' (for songbirds, as well as for insects), but only when the foliage coverage reaches its seasonal summit.

The preceding examples show that the metaphor of counterpoint, seen as a delicate balance of themes duly inscribed within a window of time, is also found in the succession of ecosystems throughout the seasons. This counterpoint of themes is far from being achieved by optimizing a topographical inventory (of vertebrate species with a special, red list protective status), like the international conventions so far have strived for. However, the unfortunate dramatic reduction of insect populations in large parts of Europe ${ }^{39}$ has completely changed the focus of biodiversity protection into the realm of invertebrate taxa. Consequently, this has stressed the importance of studying for instance the interactions between forest beetle biodiversity and sustainable fungal and tree communities in European forests (see $\mathbb{P}$ 6. A Case Study: Saproxylic Beetles and Forest Ecodiversity).

\section{A Case Study: Saproxylic Beetles and Forest Ecodiversity}

The case study presented forms a classic example of the complexity of declining biodiversity, the impact of European regulation and of controversies encountered in forest conservation and harvesting. A Red List ${ }^{40}$ representing a number of 436 so-called saproxylic beetle species, i.e. beetles

38 Ghannoum MA, Rice LB (1999).

39 Hallman CA, et al. (2017).

40 Nieto A, Alexander KNA (2010). depending on wood decay, has been selected for the whole of Europe and assessed following the IUCN methodology. ${ }^{41}$ The present Red List contains about 21 families of beetles (order of Coleoptera, Hexapoda), of which the Cerambycidae (153 species), and Elateridae (115 species) are the most numerous families contributing to this list. In terms of endemic species, the Elateridae, Eucnemidae, Lucanidae, Cucujidae and Cetoniidae provide relatively the highest percentages of endemic species. Saproxylic beetles of these families that were introduced to Europe after AD 1500 are excluded from the Red List, as well as a total of 27 species that occur in Europe outside the EU member states. However, the Red List also doesn't mention a number of important families of forest inhabiting beetles. To start with the largest European beetle family of the Ground beetles (Carabidae), which counts around 40,000 species worldwide and 2,700 species in Europe alone (!) and many of which are also very important for sustainable agriculture ${ }^{42}$ : the Carabidae are not mentioned in the European Red List.

Figure 5: Approximately true size representation of the Alpine longhorn beetle (Rosalia alpina), a species with vulnerable conservation status (IUCN 2.3; least concern ( $L C$ ) at European level, IUCN 3.1) of the family of Cerambycidae. The longhorn beetles are protected, saproxylic beetles, i.e. they live on dead wood either for food or shelter. ${ }^{43}$ One may wonder whether a certain predilection for the preservation of the Alpine longhorn, the giraffe of the beetles, is inspired by its beauty of color or proportion? 


\section{Philosophy International Journal}

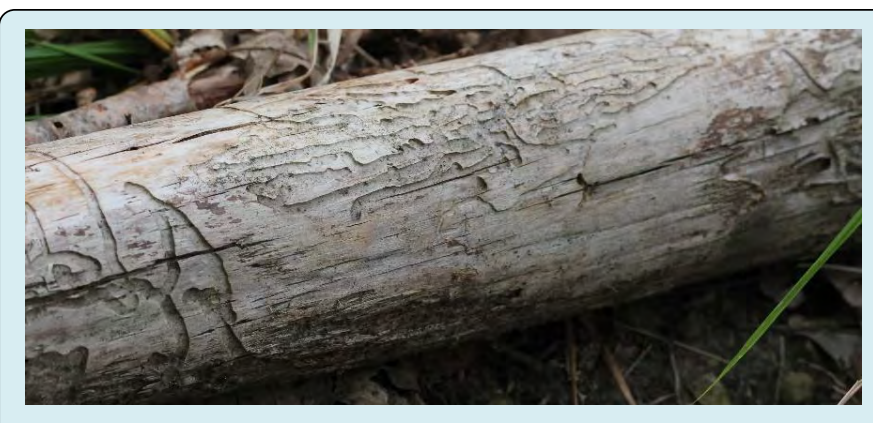

Figure 6: Galleries of bark beetles for fungal harvesting, like those formed by the European spruce bark beetle (Ips typographicus), are considered a pest for spruce forests and cause significant economic losses in many European countries. (Photo $\subset$ 2020, Biological Publishing A\&0).

Also not mentioned are the Snout beetles or 'true weevils' (Curculionidae) counting some 83,000 species worldwide. These Snout Beetles contain a number of very notorious phytophagus species, like the European spruce bark beetle (Ips typographicus, family Scolytinae), which causes a lot of damage to wood harvesting (see below), as well as the so-called Ambrosia beetles, predominantly found in the subfamilies of the Scolytinae and Platypodinae. The Ambrosia beetles are named after their symbiotic life cycles with fungi of the Ambrosiella genus (and few other genera of the Ophiostomatales, Ascomycetes order). ${ }^{44,45}$ Not only these mycophagus beetles provide an extra-ordinary demonstration of 'agricultural' harvesting in the insect world (as it is also well-known for several ant genera), ${ }^{46}$ the tree infesting habits of these weevils give them a bad reputation among forest harvesters.

Here, we have the basic ingredients of a recipe for controversy: forest harvesting and protection of the ecological biodiversity. With a budget of $€ 2,2$ billion, the EU's financial instrument LIFE has co-financed over 3,104 projects, of which only 20 are linked to actions to protect saproxylic beetles (18 to habitats and sites for saproxylic beetles and two target specific species). However, the devil is in the detail, or in the weevil, so to speak. From the harvesters viewpoint, the fight against the European spruce bark beetle(s) - obviously not mentioned in the Red list of protected beetles - may become a very expensive disaster. In Sweden, the bark beetles would have destroyed already 7 million cubic meters of wood, ${ }^{47}$ presumably worth about a

\footnotetext{
44 Jankowiak R and Bilański P (2013).

45 Chang R, Duong TA, Taerum SJ, Wingfield MJ, Zhou X and de Beer ZW (2017).

46 Mueller UG, Gerardo NM, Aanen DK, Six DL and Schultz TR (2005).

47 Starn J (2020).
}

capital of $€ 560$ million, ${ }^{48}$ comparable to $15 \%$ of the yearly forest harvest. The increased vulnerability would be the result of increasing dryness and therefore has to be regarded as a climate-related calamity. In the formerly 'usual' climate conditions, a better sap stream would enable the spruce tree to drown the weevils in their resin, but this doesn't seem to happen nowadays in Sweden. In Poland, an elaborated genetic study performed by a Polish-Czech research group, ${ }^{49}$ revealed that the pathogenicity of several Tetropium species to Norway spruce seedlings, was limited to only one Ophiostomatoid fungal species. The genus Tetropium also belongs to the family of Cerambycidae or Longhorn beetles, but does not occur in the Red List of saproxylic beetles. In Bavaria (Germany), attempts to fight the spread of bark beetles, including the spread of the feared Ips typographicus (see above), were dissuaded for ecological reasons: the partial killing of spruce plants would create new open space and potentially restore forest diversity, as well as drinking water quality ${ }^{50}$ In another Polish-Czech study, ${ }^{51}$ the health status of oak forests in southern Poland was linked to the occurrence of (previously regarded as 'fungal') Phytophthora species, ${ }^{52}$ as well as to abiotic, environmental conditions, that nowadays are presumably disadvantageous in Poland. However, the recommendation to harvest forests in advance, before infection with the spruce bark beetle might eventually occur, a recommendation that is actually propagated in the Netherlands, ${ }^{53}$ may nullify other efforts to protect forest beetle diversity and a priori jeopardize the protection of the saproxylic species in particular. This side-effect of forest harvesting is comparable to the effect of "burning forest hillsides to refresh the pastures for grazing" or to "suppress scrub development", resulting in the early death of trees and their natural regeneration. ${ }^{54}$

Apart from this, a bunch of other reasons may cause the Netherlands not only to sadly occupy a prominent position within the list of countries that cause global deforestation, ${ }^{55,56}$ but also and simultaneously, to destroy their national forest capital at a record pace: between 2001 and 2020, Global

\footnotetext{
48 Starn J (2019).

49 Jankowiak R and Kolařik M (2010).

50 Beudert B, Bässler C, Thorn S, Noss R, Schröder B, Dieffenbach-Fries H, Foullois N and Müller J (2014).

51 Jankowiak R, Stępniewska H, Bilański and Kolařik (2014).

52 The genus Phytophthora nowadays is regarded as a group of organisms belonging to the Stramenophiles kingdom (see: Allaerts W [2019]).

53 Staatsbosbeheer (2020).

54 This especially forms a threat to the endangered (IUCN 3.1) populations of the Goldstreifiger or Buprestis splendens, which species is already extinct from Germany, Austria and probably Ukraine (family of Buprestidae). (See also: Nieto and Alexander (2010), p. 20).

55 DutchNews.nl (2021).

56 World Wildlife Fund (WWF) (2021).
} 
Forest Watch estimated this deforestation in the Netherlands to approximate a $4.5 \%$ loss of the national tree cover since $2000 .{ }^{57}$ For obvious reasons, the resulting mer à boire will be the subject of another study. It stresses the viewpoint that the present discussion on the protection of saproxylic beetles is hard to keep unspoiled by huge economic interests (see above) and the invisible networks and informal powers exerted by the forest management, wood and biomass lobbyists. $^{58}$

\section{Conclusions}

The present philosophical-ecological review starts from the Foucauldian excavations of the notions of similitude and dis-similitude, originating in sixteenth-century epistemology. Alongside with Charles Darwin's remark of the biologists attempts to "define the undefinable", we disclosed the underlying stratification of biodiversity into the four dissimilitudes: chemodiversity, genodiversity, phenodiversity (also called phyllodiversity) and ecodiversity.

Looking at the global biodiversity breakdown, apart from the direct climate effects, it appears that the preferential approach of so-called higher vertebrate species conservation and red list protection measures have reached their limits. When economic interests (including tourism and other forms of recreational activities) and ecosystem sustainability questions are confronted, choices often have to be made. These aren't necessarily the right choices, especially when sufficient knowledge of the ecological processes at stake fail to the decision makers. Unfortunately, this happens in most of the complex ecosystems studied so far. It is concluded that the combination of economic premises and an insufficient knowledge basis for ecological biodiversity may result in unsuccessful but costly conservation programs that fail to protect biodiversity in the long term.

\section{References}

1. Adams MJ, Lefkowitz EJ, King AM, Carstens EB (2013) Recently agreed changes to the International Code of Virus Classification and Nomenclature. Archives of Virology 158(12): 2633-2639.

2. Allaerts W (1999) Local and global patterns during morphogenesis of the retinotectal topographical mapping in the vertebrate brain. Acta Biotheoretica 47: 99-122.

3. Allaerts W (2019) Can Lichens form a barrier for Fungi marching on? International Journal of Environment \&

57 Global Forest Watch (2021).

58 European Academies Science Advisory Council (EASAC) (2017).
Agricultural Science 3(2): 022.

4. Allaerts W (2020) Estimating Biodiversity and the Fractal Nature of Ecosystems. International Journal of Bioinformatics and Computational Biology 5(1): 15-24.

5. Allaerts W (2021). A comment on the Unified Neutral Theory of Biodiversity and Biogeography. Journal of Earth Science and Climatic Change JESCC-108.

6. Berendse F (1998) Effects of dominant plant species on soils during succession in nutrient-poor ecosystems. Biogeochemistry 42: 73-88.

7. Beudert B, Bässler C, Thorn S, Noss R, Schröder B, et al. (2014) Bark beetles increase biodiversity while maintaining drinking water quality. Conservation Letters 8(4): 272-281.

8. Birdlife International (2015) Pernis apivorus (European Honey-Buzzard). European red List of Birds (Supplementary material). In: European Red List of Birds.

9. Chang R, Duong TA, Taerum SJ, Wingfield MJ, Zhou X, et al. (2017) Ophiostomatoid fungi associated with coniferinfesting beetles and their phoretic mites in Yunnan, China. MycoKeys 28: 19-64.

10. Darwin C (1856) Letter to J.D. Hooker, 24 December 1856, University of Cambridge Archives, Darwin Correspondence Project.

11. Duris P (2006) Linné - Classer la nature. Paris: Pour la Science. (Dutch transl. by Kortbeek T [2007\}, Linnaeus - De ordening van plant en dier. Wetenschappelijke biografie, Amsterdam: Veen Magazines.), 18: 1.

12. DutchNews.nl (2021) Dutch at forefront of tropical forest destruction. WWF claims.

13. European Academies Science Advisory Council (EASAC) (2017) Multi-functionality and sustainability in the European Union's forests.

14. European Commission (EC)(2014a) Evaluation Study to support the Fitness Check of the Birds and Habitats Directives. Brussels: Milieu Ltd.

15. European Commission (EC)(2014b) An introduction to the EU Habitats and Birds Directives.

16. European Environment Agency (EEA) (1979) Convention on the Conservation of European Wildlife and Natural Habitats - Bern Convention. European Commission.

17. Foucault M (1966) Les Mots et les Choses. Paris: Editions Gallimard. 


\section{Philosophy International Journal}

18. Foucault M (1970) The Order of Things. An Archaeology of the Human Sciences. New York: Vintage Books, Random House Inc.

19. Ghannoum MA, Rice LB (1999) Antifungal agents: mode of action, mechanisms of resistance, and correlation of these mechanisms with bacterial resistance. Clinical Microbiology Reviews 12(4): 501-517.

20. Gladysheva TB, Oden KL and Rosen BP (1994) Properties of the arsenate reductase of plasmid R773. Biochemistry 33: 7288-7293.

21. Global Forest Watch (2021) Netherlands Deforestation Rates \& Statistics.

22. Hallman CA, Sorg M, Jongejans E, Siepel H, Hofland N, et al. (2017) More than 75 percent decline over 27 years in total flying insect biomass in protected areas. PLOS one 12: e0185809.

23. Hestrin R, Hammer EC, Mueller CW and Lehmann J (2019) Synergies between mycorrhizal fungi and soil microbial communities increase plant nitrogen acquisition. Communications Biology 2: 233.

24. Hofstadter DR $(1979,1985)$ Gödel, Escher, Bach: an eternal golden braid. Jonkers R (Dutch transl. [1985]), Gödel, Escher, Bach: een eeuwige gouden band. Amsterdam: Contact.

25. Hubbell SP (2001) A Unified Neutral Theory of Biodiversity and Biogeography. Princeton, NJ: Princeton University Press.

26. Hug K, Maher WA, Stott MB, Krikowa F, Foster S, et al. (2014) Microbial contributions to coupled arsenic and sulfur cycling in the acid-sulfide hot spring Champagne Pool, New Zealand. Frontiers in Microbiology 5: 569.

27. International Union for Conservation of Nature (IUCN) (2001) Red List Categories and Criteria: Version 3.1. IUCN Species Survival Commission. Gland, Switzerland: IUCN.

28. International Union of Pure and Applied Chemistry (IUPAC) (2004) Periodic table of the elements (Untitled document).

29. Jankowiak R, Bilański $P$ (2013) Diversity of ophiostomatoid fungi associated with the large pine weevil, Hylobius abietis, and infested Scots pine seedlings in Poland. Annals of Forest Science 70: 391-402.

30. Jankowiak R, Kolařik M (2010) Diversity and pathogenicity of Ophiostomatoid fungi associated with Tetropium species colonizing Picea abies in Poland. Folia
Microbiologica 55(2): 145-154.

31. Jankowiak R, Stępniewska H, Bilański, Kolařik (2014) Occurrence of Phytophthora plurivora and other Phytophthora species in oak forests of southern Poland and their association with site conditions and the health status of trees. Folia Microbiologica 59: 531-542.

32. Kromp B (1999) Carabid beetles in sustainable agriculture: a review on pest control efficacy, cultivation aspects and enhancement. Agriculture, Ecosystems and Environment 74(1-3): 187-228.

33. Macià FX, Menchetti $\mathrm{M}$, Corbella $\mathrm{C}$, Grajera J, Vila R (2019) Exploitation of the invasive Asian Hornet Vespa velutina by the European Honey Buzzard Pernis apivorus. Bird Study 66(3): 425-429.

34. Mandelbrot BB (1983) The Fractal Geometry of Nature. New York: W.H. Freeman and Company.

35. Mazzola G (2002) The Topos of Music, Geometric Logic of Concepts, Theory, and Performance. Basel, Switzerland: Birkhäuser.

36. Mazzola G (2017) The Topos of Music. I. Theory. $2^{\text {nd }}$ (Edn.), Computational Music Science. Springer.

37. Mueller UG, Gerardo NM, Aanen DK, Six DL, Schultz TR (2005) The evolution of agriculture in insects. Annual Review of Ecology, Evolution and Systematics 36: 563569.

38. Nederlandse Publieke Omroep (NPO) (2020) Podcast, containing fragments of interview with Pierre Boulez.

39. Nieto A, Alexander KNA (2010) European Red List of Saproxylic Beetles. Luxembourg: Publications Office of the European Union.

40. Oberdorfer E (1957) Süddeutsche Pflanzengesellschaften. Jena: Fischer.

41. Rapoport DL (2011) On the Fusion of Physics and Klein Bottle logic in Biology, Embryogenesis and Evolution. NeuroQuantology 9(4): 842-861.

42. Reynolds CW (1987) Flocks, Herds and Schools: a distributed behavioral model. Computer Graphics 22(4): 25-34.

43. Runge F (1966) Die Pflanzengesellschaften Westfalens und Niedersachsens. Münster: Aschendorff.

44. Speight MCD (1989) Saproxylic invertebrates and their conservation. Nature and Environment series, No. 42. Strasbourg: council of Europe Publishing. 
45. Starn J (2019) This tiny bug could put a \$ 625 million hole in Sweden's forests. Bloomberg.

46. Starn J (2020) Spruce bark beetles are ruining Swedish forests at a record pace. Bloomberg.

47. Staatsbosbeheer (2020) Maatregelen letterzetter Vijlenerbos [in Dutch]. Staatsbosbeheer: Werk in Uitvoering.

48. Thom R (1974) Modèles mathématiques de la morphogenèse. Recueil de textes sur la théorie des catastrophes et ses applications [in French]. Paris VI: Inédit, Union Générale d'Éditions (collection 10/18).

49. Thompson DW $(1917,1961$ Ed.) On Growth and Form
(Abridged Edition by JT Bonner). Cambridge: Cambridge University Press.

50. Trimble V (1996) The Origin and Evolution of the Chemical Elements. In: Malkan MA, Zuckerman B [Eds.]. The origin and evolution of the universe. Sudbury, MA: Jones and Bartlett Publishers.

51. Wilson EO (1975) Sociobiology: The New Synthesis. Cambridge MA: Harvard University Press.

52. World Wildlife Fund (WWF) (2021) EU consumption responsible for $16 \%$ of tropical deforestation linked to international trade - new report. WWF position paper on new EU legislation on deforestation. 